\title{
Identification of Landslide Potentials Triggered by Earthquakes in the Slopes of the Kalirejo Region, Kokap District, Kulon Progo, Yogyakarta, Indonesia
}

\author{
$1^{\text {st }}$ Rizqi Prastowo ${ }^{1}, 2^{\text {nd }}$ Obrin Trianda ${ }^{2}, 3^{\text {rd }}$ Sely Novitasari ${ }^{3}, 4^{\text {th }}$ Rofiqul Umam $^{4}, 5^{\text {th }}$ Muhamad $^{\text {Mand }}$ \\ Syazali ${ }^{5}, 6^{\text {th }}$ Rahmad Junaidi ${ }^{6}$ \\ $\underline{\text { rizqi@itny.ac.id }}{ }^{1}, \underline{\text { obrintrianda.lahat@gmail.com }}{ }^{2}, \underline{\text { selynovita23@gmail.com }}^{3}$, \\ egk71822@kwansei.ac.jp ${ }^{4}, \underline{\text { muhamadsyazali@radenintan.ac.id }}{ }^{5}, \underline{\text { ahmad_junaidi@uinsby.ac.id }}{ }^{6}$ \\ ${ }^{1}$ Departement of Mining Engineering, Institute of Technology National Yogyakarta, Yogyakarta \\ ${ }^{2}$ Departement of Geology Engineering, Institute of Technology National Yogyakarta, Yogyakarta \\ ${ }^{3}$ Departement of Civil Engineering, Institute of Technology National Yogyakarta, Yogyakarta \\ ${ }^{4}$ School of Science and Technology, Kwansei Gakuin University, Sanda, Japan \\ ${ }^{5}$ Department of Mathematics Education, Universitas Islam Negeri Raden Intan Lampung, Indonesia \\ ${ }^{6}$ Faculty of Science and Technology, Universitas Islam Negeri Sunan Ampel Surabaya, Indonesia
}

\begin{abstract}
Landslide is a disaster that is caused by several factors, among others, the condition of the surface sediment layer, vibration and the slope of the slopes. This research aims to know the potential landslides triggered off tremors of an earthquake by using the value approach ground shear strains obtained from data analysis microtremor. Research location in the village of Kalirejo, Kokap, Kulon Progo. The village Kalirejo is an area of hills in Kulon Progo Regency, Yogyakarta, which lies about $14 \mathrm{~km}$ from the Indian Ocean so it has potential for avalanche induced earthquakes are relatively high. Measurement mikrotremor do 15-point measurement with duration of 30 minutes. Data recording microtremor and then processed using the software Geopsy. The result value of the Ground shear strain are between 0.0001480.006819 so that the area had landslide with the potential of ground movement.
\end{abstract}

Keywords: Landslide, Kalirejo, Mikrotremor, Ground shear strain.

\section{Introduction}

Ground cracks are soil cracks that may be caused by decreasing groundwater levels, earthquakes and other geological phenomena. The geological phenomenon that triggered the fracture of the land is an earthquake like what happened on the island of Lefkada, Greece[1]. Broken ground can cause damage, including cracks or collapse, pipeline damage, canal damage or breakage[2], cracked building foundations / broken building walls, damage to agricultural areas, livestock and animals injured or dead, broken or curved railroads, damage casing of boreholes, disruption of irrigation canals, contaminated groundwater, sudden formation of water basins, human casualties injured or dead[3].

Land fractures generally occur in boundary areas between soil layers that experience and do not experience land subsidence or in areas with different rates of land subsidence. This difference in soil degradation occurs in areas that experience excessive water uptake, earthquakes and have a large height difference in bedrock (layer below the surface sediment layer) in a narrow area (large slope)[4]. Efforts to reduce the risk of soil fracture can be done by mapping areas prone to fracturing using microtremor measurements. Microtremor measurements can be used to determine the geological conditions and thickness of the surface sediment layer that describes the condition of the surface of the bedrock (layer below the surface sediment layer) in an area. In addition, the results of microtremor measurements and maximum 
ground vibration acceleration (PGA) can be used to determine the ground shear strain value which states the strain level of the surface sediment and its effects due to earthquake[5].

\section{Methods}

\subsection{Location of sampling data (Kalirejo Region)}

The stratigraphic structure of the Kulonprogo Mountains region can be distinguished in groups of sedimentary rocks and volcanic rock groups. Sedimentary rocks as a base are composed of predominantly quartz sandstone and limestone called the Nanggulan Formation. Sedimentary rocks of the Nanggulan Formation are the basis of the volcanic rocks of the Kebobutak Formation. The Nanggulan and Kebobutak Formations are intruded by shallow intrusive rocks in the form of microdiorite, andesite and dacite which in general have undergone changes. This group of volcanoes is covered in an inconsistent manner by shallow marine deposits Jonggrangan Formation and Sentolo Formation[6].

\subsection{Microtremor data acquisition}

This method was used to identify the predominant resonant frequency of a sedimentary layer using the horizontal-to-vertical ratio of the Fourier transform from microtremor data. The comparison between the fundamental frequency obtained from microtremor $\mathrm{H} / \mathrm{V}$ spectral ratios and the receiver functions of earthquake recordings or explosion data have allowed researchers to conclude that microtremor $\mathrm{H} / \mathrm{V}$ spectral ratios provide reliable estimates of the fundamental frequencies of soil deposits [7]. Research conduct to establish the H/V spectral ratio in site characterization, in addition to microzonation and urban vulnerability studies $[8,9,10]$. In addition to the $\mathrm{H} / \mathrm{V}$ microtremor research for identification of landslides in Italy [11], and soil movement[12]. Geological research has also been carried out in the Kalirejo area with the potential for rock fall avalanches[13] and geophysical research on the thickness of weathered layers[14].

The importance of seismic site effect can be explained in term of the earthquake wave which propagates and caused the soil and ground amplification, while these properties are controlled by the frequency contents of ground motions. Ground amplification analysis is carried out through a $10 \mathrm{~km}$ long lines with $500 \mathrm{~m}$ interval of microtremor data acquisition using a weak-motion seismometer[15].

15 measurement points have been conducted to measure the dominant period of the earth and behavior dynamically from soil and rock properties in the Kalirejo, Kokap, Yogyakarta area Figure 1. Measurements are carried out with a duration of 30 minutes each point and a sampling rate of $100 \mathrm{~Hz}$. Measurements were taken around Kukusan Mountain in Kalirejo Village. To prevent signal interference, measurements are taken at a distance of $7 \mathrm{~mm}$ from the road and the electric pole. The time of measurement is during the day, because the condition of the village is quiet. The results of the microtremor measurements were then processed based on the HVSR method[16] using Geopsy software. Ground shear strain values that describe the condition of soil dynamics[17], calculated based on the results of HVSR processing and maximum ground vibration acceleration in bedrock[18]. The research design map can be seen in Figure 2. 


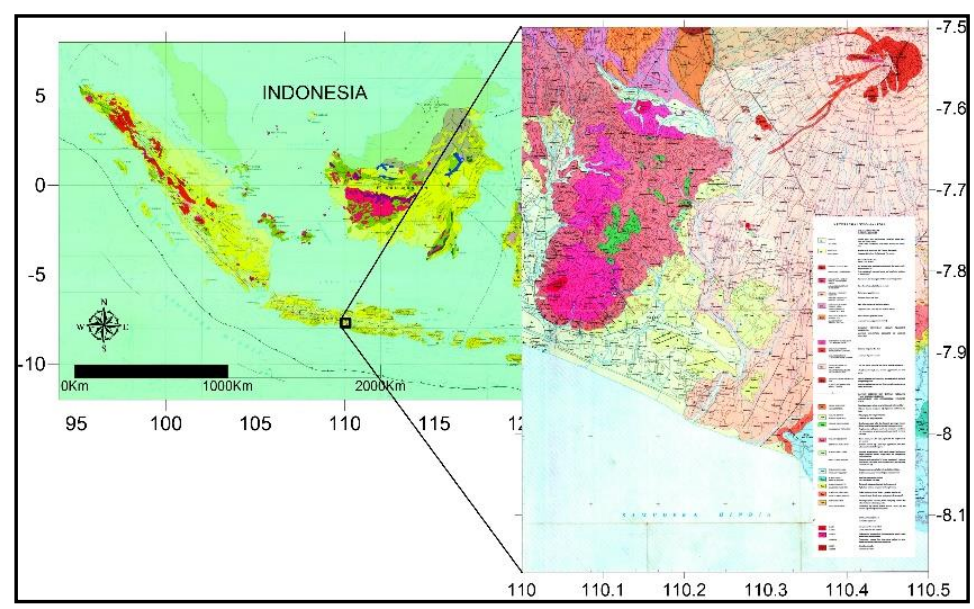

Fig. 1. The map of Kalirejo Region, Kokap District, Kulon Progo, Yogyakarta, Indonesia

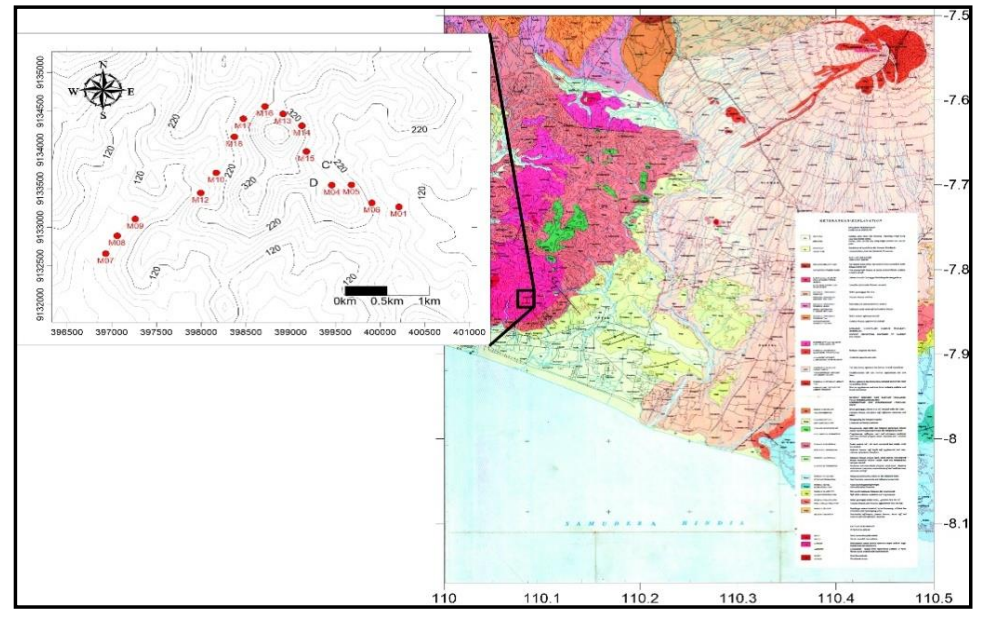

Fig. 2. Location of data collection in this study

\section{Result and Discussion}

The result of HVSR analysis is the peak value of the HVSR curve that describes the amplification value and the dominant frequency value shown in Figure 3. The dominant frequency value is inversely proportional to the thickness of the sediment / soil [4]. The first fundamental frequency of $\mathrm{H} / \mathrm{V}$ ratio mostly reflects the $\mathrm{S}$-wave velocity of sediments and it is therefore used for validation of $S$-wave velocity structures determined by geotechnical approach [8]. In determining the value of ground shear strain, first look for the $S$ wave velocity values and Peak Ground Accelaration (PGA). in this study the $S$ wave velocity value uses speed at USGS. While the PGA value uses earthquake history data in the study area. The earthquake catalog in this study was also obtained from USGS provided that a magnitude of more than 5 Mw. Figure 3 shows the results of Geopsy processing at points M05 and M07. 


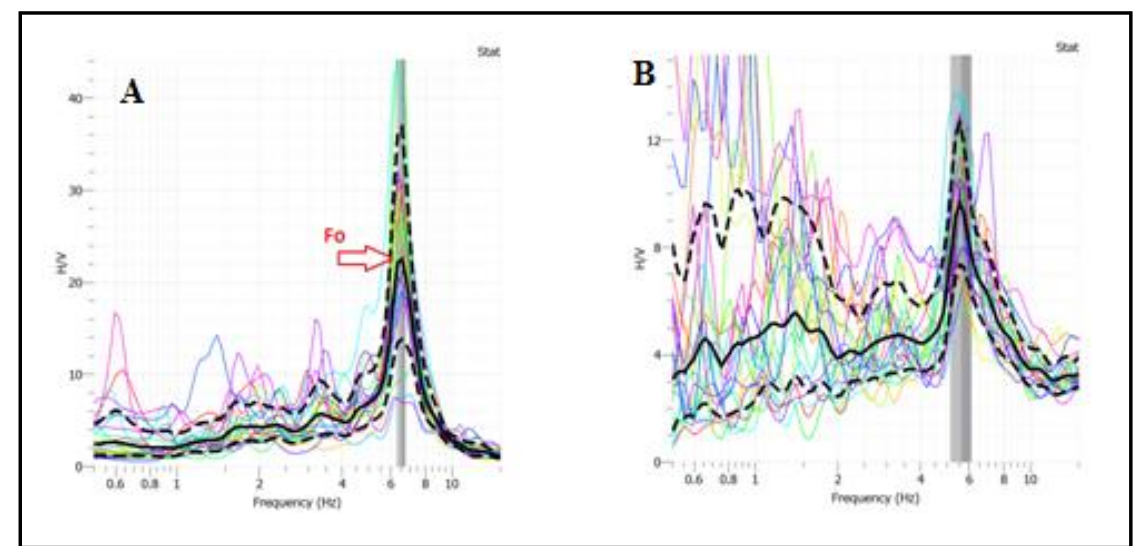

Fig. 3. Results from Geophysics processing with: (A) the signal at point M05 has a natural frequency of $6.6 \mathrm{~Hz}$; (B) the signal at point M07 has a natural frequency of $5.5 \mathrm{~Hz}$

In calculating the ground shear strain value, the base rock PGA value used is a PGA value from the USGS earthquake catalog which has a magnitude of more than $5 \mathrm{Mw}$. The interpolation results of ground shear strain values are shown in Figure 4. The ground shear strain values in Figure 4 show values $>1000 \times 10^{-6}$ at points M01, M05, M07, M16, and M17. So that the point area is prone to deformation and land movement if triggered by earthquakes. Low ground shear strain values at points M4, M6, M8, M9, M12, M13, M14, M15 and M8 are probably caused by thin soil layers (high frequency values).

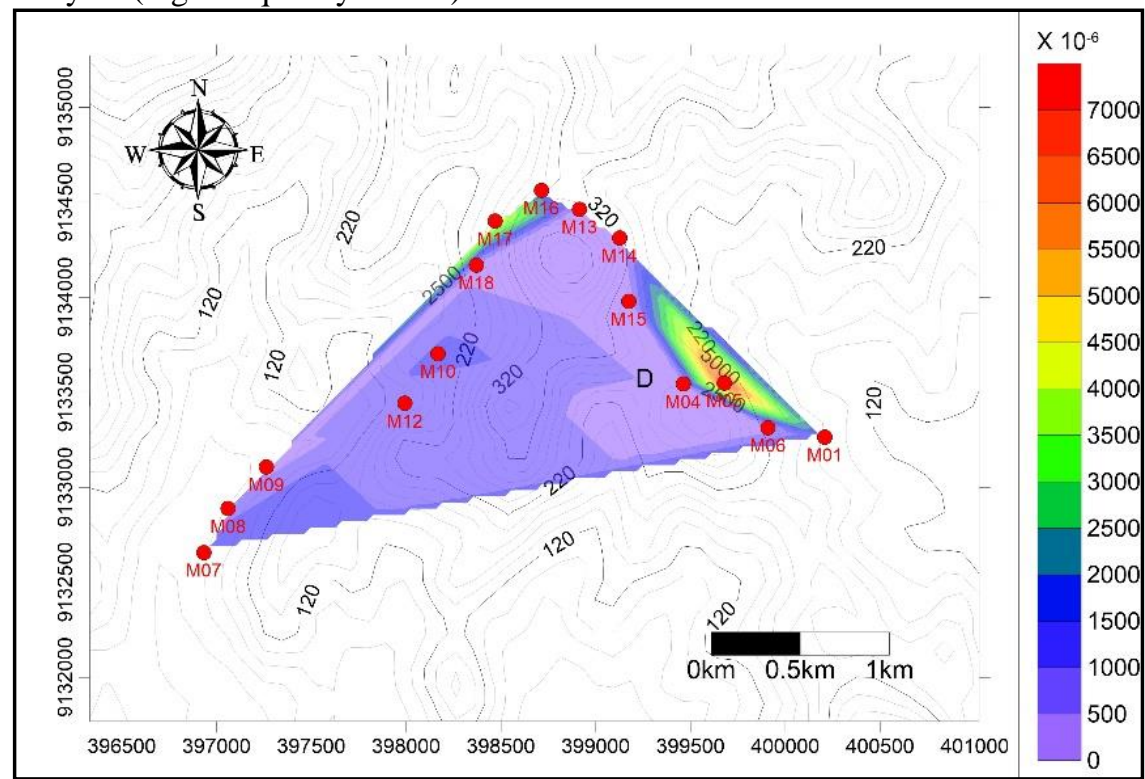

Fig. 4. Map of ground shear strain values 


\section{Conclusion}

Ground shear strain calculation to identify potential landslide that is triggered by earthquake zones in Kalilrejo Village, Kokap sub district using HVSR measurement lead to the following conclusion is the highest value of ground shear strain was observed in coordinate (399678.3, 9133549), at 0.06819 , so that it is prone to deformation and soil movement. So that it is necessary to carry out landslide mitigation measures in the research areas such as reforestation and engineering of slope strengthening to avoid or minimize losses and casualties due to landslides.

\section{Acknowledgments}

Thanks to DRPM Kemenristekdikti as a supporter of funds hibah Penelitian Dosen Pemula tahun anggaran 2018. 


\section{References}

[1] G. Papathanassiou, S. Valkaniotis, A. Ganas, N. Grendas, and E. Kollia, "The November 17th, 2015 Lefkada (Greece) strike-slip earthquake: Field mapping of generated failures and assessment of macroseismic intensity ESI-07," Engineering Geology, vol. 220, no. July 2016, pp. 13-30, 2017.

[2] I. S. Wekke, Z. Sabara, M. A. Samad, A. Yani, R. Umam, and M. U. Palu, "Earthquake , Tsunami , And Society Cooperation: Early Findings In Palu Post Of Indonesia Disaster," INA-Rxiv Papers, 2019.

[3] I. S. Wekke et al., "Educational Institution on Responding Disasters in Palu of Indonesia," INA-Rxiv Papers, 2019.

[4] Marjiyono, Ratdomopurbo, Suharna, H. M. H. Zajuli, and R. Setianegara, "Geologi bawah permukaan dataran klaten berdasarkan interpretasi data mikrotremor," J.G.S.M., vol. 15, no. 1, pp. 3-9, 2014.

[5] S. Sismanto, U. Yasmita, and F. Jusmi, "Interpretation of the gravity and magnetic anomalies of the geothermal subsurface structure area in Pamancalan, Lebak, Banten , West Java , Indonesia," Arabian Journal of Geosciences, vol. 11, no. 396, 2018.

[6] A. Widagdo, S. Paramumijono, A. Harijoko, and A. Setiawan, "Kajian Pendahuluan Kontrol Struktur Geologi terhadap Sebaran Batuan-batuan di Daerah Pengunungan Kulonprogo Yogyakarta,” Proceeding Seminar Nasional Kebumian ke 9, pp. 9-20, 2016.

[7] M. Mokhberi, "Vulnerability evaluation of the urban area using the H/V spectral ratio of microtremors," International Journal of Disaster Risk Reduction, vol. 13, pp. 369-374, 2015.

[8] K. Sassa, P. Canuti, and Y. Yin, "Investigation to the Local Site Effects During Earthquake Induced Ground Deformation Using Microtremor Observation in Yogyakarta, Central Java-Indonesia," Landslide Science for a Safer Geoenvironment, vol. 3, pp. 241-249, 2014.

[9] Y. Zhang, J. Zhang, G. Chen, L. Zheng, and Y. Li, "Effects of vertical seismic force on initiation of the Daguangbao landslide induced by the 2008 Wenchuan earthquake," Soil Dynamics and Earthquake Engineering, vol. 73, pp. 91-102, 2015.

[10] P. S. Thein et al., "Estimation of Seismic Ground Motion and Shaking Palu City, Central Sulawesi Province, Indonesia," World Academy of Science, Engineering and Technology International Journal of Geological and Environmental Engineering, vol. 8, no. 5. pp. 308-319, 2014.

[11] V. Pazzi, L. Tanteri, G. Bicocchi, M. D’Ambrosio, A. Caselli, and R. Fanti, "H/V measurements as an effective tool for the reliable detection of landslide slip surfaces: Case studies of Castagnola (La Spezia, Italy) and Roccalbegna (Grosseto, Italy)," Physics and Chemistry of the Earth, vol. 98, pp. 136-153, 2017.

[12] D. Petley, J. Barlow, T. Wright, A. Densmore, I. Barisin, and N. Rosser, "Seismicallyinduced mass movements and volumetric fluxes resulting from the $2010 \mathrm{Mw}=7.2$ earthquake in the Sierra Cucapah, Mexico," Geomorphology, vol. 230, pp. 138-145, 2014.

[13] R. Prastowo, O. Trianda, and S. Novitasari, "Identifikasi Kerentanan Gerakan Tanah Berdasarkan Data Geologi Daerah Kalirejo , Kecamatan Kokap , Kabupaten Kulonprogo ," Kurvatek, vol. 3, no. 2, pp. 31-40, 2018.

[14] O. Trianda, R. Prastowo, and S. Novitasari, "Identifikasi Ketebalan Lapisan Lapuk di Daerah Kalirejo , Kulonprogo Berdasarkan Pengukuran Mikrotremor dalam Upaya Mitigasi Tanah Longsor,” Seminar Nasional ReTII XIII, vol. XIII, no. November, pp. 246-253, 2018. 
[15] A. H. A. Latiff and A. Esmail Khalil, "Seismic Site Effect along Bukit Tinggi Fault Line from Microtremor Analysis," IOP Conference Series: Earth and Environmental Science, vol. 244, p. 12042, 2019.

[16] M. Herak, "ModelHVSR-A Matlab® tool to model horizontal-to-vertical spectral ratio of ambient noise," Computers and Geosciences, vol. 34, no. 11, pp. 1514-1526, 2008.

[17] Y. Nakamura, "A method for dynamic characteristics estimation of subsurface using microtremor on the ground surface," Railway Technical Research Institute, Quarterly Reports, vol. 30, no. 1, 1989.

[18] Y. Fukushima and T. Tanaka, "A new attenuation relation for peak horizontal acceleration of strong earthquake ground motion in Japan," Bulletin of the Seismological Society of America, vol. 80, no. 4, pp. 757-783, 1990. 